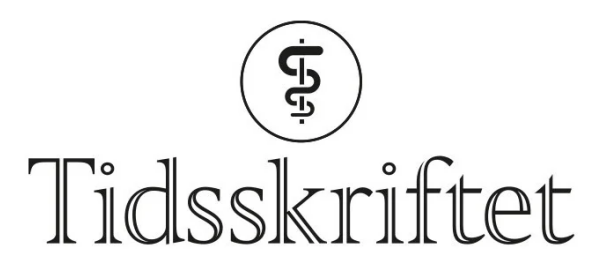

DEN NORSKE LEGEFORENING

\title{
Viktig bok om seksuelt overførbare infeksjoner
}

ANMELDELSER

ÅSE HAUGSTVEDT

Overlege og leder av Nasjonal kompetansetjeneste for seksuelt overførbare infeksjoner

Harald Moi, Jan Martin Maltau

Seksuelt overførbare infeksjoner og genitale hudsykdommer

4. utg. 294 s, tab, ill. Oslo: Gyldendal Akademisk, 2021. Pris NOK 499

ISBN 978-82-05-55966-o

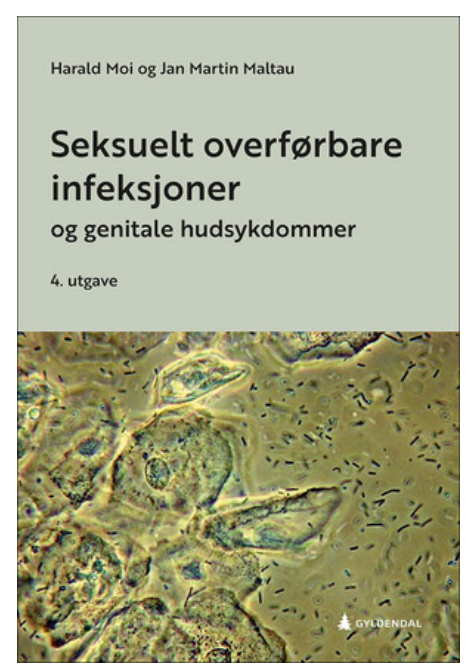

Dette er den 4. utgaven av boka, som ble utgitt for første gang i 2002. Boka er ment som en lærebok for medisinstudenter og leger under spesialisering i dermatovenerologi. For fastleger og andre, og da spesielt urologer, infeksjonsmedisinere, gynekologer og dermatovenerologer, er den tenkt til å være en praktisk veileder og oppslagsverk i en hektisk klinisk hverdag.

Boka er meget oversiktlig og lett å slå opp i. Illustrasjonene og fotografiene er av høy kvalitet og bidrar til en god leseropplevelse. 
Strukturen er lik som i de tidligere utgavene. Første del tar for seg mer generelle tema som lovverk, mikrobiologi, utstyr og rutiner for kontordiagnostikk. Siste del handler om de enkelte infeksjonene samt genitale hudsykdommer og neoplastiske lidelser med utfyllende informasjon om diagnostikk og behandling. Språket er revidert: For eksempel heter det nå smittesporing og ikke smitteoppsporing, og i stedet for salpingitt brukes nå akutt bekkeninfeksjon (ABI).

Nytt i denne utgaven er et eget kapittel om mollusker samt egne avsnitt om vaksine mot humant papillomavirus (HPV), om lymfogranuloma venerum (LGV) og om preeksponeringsprofylakse (PrEP). Terapianbefalingene er oppdaterte.

Det finnes noen små «skjønnhetsfeil»: Både Kenacutan-krem og Clindamycin-krem har gått ut av produksjonen, og benzylbezoat 33 \%-liniment til skabbehandling finnes nå også i ny formula. Man trenger heller ikke lenger være spesialist i gynekologi, infeksjonsmedisin eller dermatovenerologi for å søke om herpesmedisin på blå resept til HELFO.

Jeg vil på det sterkeste anbefale boka som lærebok, spesielt for medisinstudenter, dermatovenerologer, infeksjonsmedisinere, gynekologer og urologer. Som oppslagsverk for leger i allmennpraksis og helsestasjonsleger kan den også anbefales på det sterkeste. Man må imidlertid være oppmerksom på at retningslinjene for behandlinger endres raskt. Det anbefales derfor å slå opp i de sist reviderte nasjonale retningslinjer for antibiotikabruk når man skal velge antibiotikabehandling.

Publisert: 10. januar 2022. Tidsskr Nor Legeforen. DOI: 10.4045/tidsskr.21.0791

(C) Tidsskrift for Den norske legeforening 2023. Lastet ned fra tidsskriftet.no 26. april 2023. 